\title{
The Emergency Remote Learning Experience of University Students in Indonesia amidst the COVID-19 Crisis
}

\author{
Maila D. H. Rahiem \\ UIN Syarif Hidayatullah Jakarta \\ Jakarta, Indonesia \\ http://orcid.org/0000-0002-5618-2486
}

\begin{abstract}
This study aimed to explore and interpret the lived experience of Indonesian university students in emergency remote learning (ERL) during the COVID-19. Methods of the investigation was a qualitative phenomenological approach involving 80 students from the Social Science Education Program at a public university in Jakarta. Understanding their experience was achieved through a rigorous analysis of the participants' diaries and reflective essays and an online focus group. Results revealed that the students' experiences fell into two overarching themes, each with related sub-themes. The two identified themes and subthemes were: (a) blended learning, with the subthemes of e-learning, m-learning and conventional learning, and (b) paradoxical learning, with the sub-themes of flexible learning and challenging learning. By studying how university students learned during COVID-19, we could help ensure the efficacy of ongoing ERL and better incorporate similar programs in the future if this ever happens again.
\end{abstract}

Keywords: emergency remote learning; online learning; higher education; COVID-19

\section{Introduction}

The COVID-19 global pandemic has created entirely unprecedented situations that have greatly affected people's lives. With doubts remaining at present over how and when it will end, the question remains whether things will ever go back to the way they were before the pandemic began with many skeptics remaining doubtful (Lee et al., 2010).The World Health Organization (WHO) has warned that COVID-19 is likely to haunt the world for a long time and that the planet will only return to normal once a viral strain vaccine has been discovered. There are currently ten candidate vaccines in clinical trials worldwide and 126 candidate vaccines in pre-clinical trials (World Health Organization, 2020b). Anthony Fauci, MD, director of the US National Institute of Allergy and Infectious Disease, said that if all goes well, a vaccine might be available in November or December of this 
year (McCarthy, 2020; Reynolds, 2020). However, even after a vaccine has been approved, there remains an immense challenge to generate enough of it for the world's population (Felter, 2020).

Presently (Early June 2020), in Indonesia and some other countries, the number of cases is still increasing at an alarming rate. The number of patients nationwide who have tested positive is up to 36,406 , with patients who have recovered recorded as 13,213 people, and patients who have died totaling 2,048 people (Task Force for the Acceleration of COVID-19, 2020). COVID-19 has spread to 34 provinces, meaning that it has spread to all of the provinces across the Indonesian archipelago, and 391 out of 514 municipal districts have been infected (National Agency for Disaster Management, 2020). So far, the percentage of Indonesia's death rate, which is above 6 percent, is rated in the high category. The total number of cases worldwide is also still increasing, with 7,127,753 confirmed cases of COVID-19 spread across 216 countries, including 407,159 deaths, reported to WHO (World Health Organization, 2020c).

As a result of the threat posed by COVID-19, educational institutions have hurried to shift courses to virtual classrooms. Many institutions have chosen to cancel all face-to-face classes, including laboratories and other learning activities, and have required students to study remotely from home to help avoid the spread of the virus that causes COVID-19. The UN Educational, Scientific, and Cultural Organization(UNESCO, 2020) estimated that 129 countries had implemented national school closures (data from June 10, 2020). These nationwide closures have impacted almost 63.3 percent of the world's student population or 1,109,020 learners. Several other countries have implemented localized closures impacting millions of additional learners (approximately 488,198,235 learners). The total number of affected learners due to nationwide closures and localized closures totals $1,725,082,528$. The trend of nationwide closures has decreased from previous figures recorded on April 1 - 4, 2020, where 1,598,099,000 learners, or $91.3 \%$ of total enrolled learners, were recorded as being affected due to the nationwide closures policy in 195 countries. However, the total affected number (nationwide and localized) is relatively the same, starting from March 26, 2020. This data indicates that although the national closures policy has begun to be revoked in some areas and regions, schools and local governments have continued to implement remote learning.

In Indonesia, nationwide school closures began on March 23, 2020, while localized closures in some provinces, e.g., DKI Jakarta, Central Java, Banten, West Java, and Aceh, started early on March 16, 2020 (Kumparan, 2020). The national school closures have impacted 60.2 million learners and 2.3 million educators who study or teach at 425,451 educational institutions from early childhood to higher education. 
Table 1: Number of affected academic institutions, learners and educators in Indonesia

(Ministry of Education and Culture, 2019, 2020c, 2020a, 2020d, 2020b)

\begin{tabular}{|l|c|c|c|}
\hline \multicolumn{1}{|c|}{ Level } & $\begin{array}{c}\text { Academic } \\
\text { Institutions }\end{array}$ & Learners & Educators \\
\hline Early Childhood Education & 202,991 & $6,543,758$ & 666,678 \\
\hline Elementary School & 149,435 & $25,203.371$ & 556,969 \\
\hline Junior High School & 40,559 & $10,112,022$ & 302,116 \\
\hline Senior High School & 13,495 & $4,976,127$ & 212,715 \\
\hline $\begin{array}{l}\text { Vocational School (Equivalent to Senior High } \\
\text { School) }\end{array}$ & 14,301 & $5,242,851$ & 217,986 \\
\hline College/University & 4,670 & $8,043,480$ & 294,820 \\
\hline TOTAL & 425,451 & $60,121,609$ & $2,251,284$ \\
\hline
\end{tabular}

School closures are based on the previous studies of influenza outbreaks that resulted from social interactions between students and teachers that disrupted the learning process (Jackson et al., 2016). Cauchemez et al., $(2008,2009)$ quantified the role of schools in influenza epidemics and predicted the effect of school closures during a pandemic in France. They found that sustained school closures during a pandemic could reduce the total number of cases by 13-17 percent (1823 percent in children), while during the height of the attack the rate could be as much as 39-45 percent (47-52 percent in children). The effect of school closures would be minimized if it proved difficult to sustain low contact rates among children for a prolonged time. Earn (2012) looked at the associations between the occurrence of H1N1 (pH1N1) pandemic influenza in Alberta, Canada in 2009 and school closures or weather changes, and calculated the impact of school closures and weather changes on the transmission of pH1N1. Mathematical models indicated that school closures decreased transmission among school-aged children by more than 50 percent, which was a critical factor in interrupting transmission. The models also showed that seasonal changes in weather conditions had a significant effect on the epidemic's temporal structure.

School closure is one of the critical components of numerous non-pharmaceutical prevention strategies in many countries to help reduce the number of cases and slow the spread of the disease, mainly if vaccines or antivirals are not available or are ineffective due to resistance (Glass et al., 2006; Institute of Medicine, 2006; Moscona, 2005; Sadique et al., 2008). School closure policies in various countries occur in quick succession as a measure to contain the COVID-19 virus. Lee (2020) argues that school closures alone may not be enough to stop the outbreak, but that if it continues for at least eight weeks, could delay the outbreak peak by up to a week, providing adequate time for a second more successful intervention, such as vaccination.

In this study, the researcher used the term "Emergency Remote Learning (ERL)" to illustrate the education that took place during school closure, not online or virtual 
learning, since well-planned online learning experiences are substantially different from those that are delivered online in response to a crisis or catastrophe. Hodges et al. (2020) call it Emergency Remote Teaching (ERT). ERT is a temporary change from instruction delivery to alternative delivery due to crisis circumstances. It requires the use of entirely remote teaching approaches for instruction or education that would otherwise be provided face-to-face or as blended or hybrid courses, and which will revert to that model once the crisis or emergency has finished. The primary objective in this context is not to re-create a stable educational environment, but rather to provide immediate access to education and training in a manner that is easy to develop and easily accessible during an emergency or crisis. Millman (2020) described the situation as emergency remote teaching and learning - or "pandemic pedagogy."

This study focused on understanding how remote learning during COVID-19 pandemic has been conducted in a tertiary education institution by analyzing university students' perspectives and experiences. The limited research was conducted recently in Indonesia during the midst of the COVID-19 pandemic. Most of the existing research conducted is in Indonesian, published in Indonesian journals, focuses on either primary or secondary education, or education in general (the level of education is not explained). Examples of this include, "COVID-19 impact on the implementation of online learning in primary schools" (Aji et al., 2020); "Education during the COVID-19 pandemic" (Khasanah et al., 2020); "Studying Mathematics in the COVID-19 era" (Abidin, 2020); and "Online learning in the middle of the COVID-19 pandemic" (Firman \& Rahayu, 2020).

There are also several articles on learning in higher education during the COVID19 pandemic. These articles are written in Indonesian, with limited data and have not been published through peer-reviewed processes such as "Students' learning typology in online learning" (Ramdhan et al., 2020); "Google Classroom-online learning of Biology education students during the COVID-19 outbreak"(Suhada et al., 2020); "Ordinal Regression analysis to see the effect of online learning media on students' enthusiasm in the COVID pandemic era" (Meiza et al., 2020).

Some articles published in peer-reviewed Indonesian journals focus on online learning of COVID-19 at the college level. However, they were published in April, where the learning from home experience had only been in operation for a few weeks. Experiences from a short implementation time are unlikely to offer a full picture of home-based teaching and learning activities, while there was also minimal use of references. The published articles are "The impact of COVID-19 online learning activities in a Christian university in Indonesia"(Windhiyana, 2020); "Implementation of the performance model of DeLone and McLean Knowledge Systems For Zoom application-based learning systems during the COVID-19 pandemic"(Hidayatullah et al., 2020); "Perception of students majoring in Early Childhood Islamic Education towards online Lectures in the COVID-19 pandemic period"(Anhusadar, 2020); and "Variations of models and learning platforms for prospective teachers during the COVID-19 pandemic period"(Gunawan et al., 2020). 


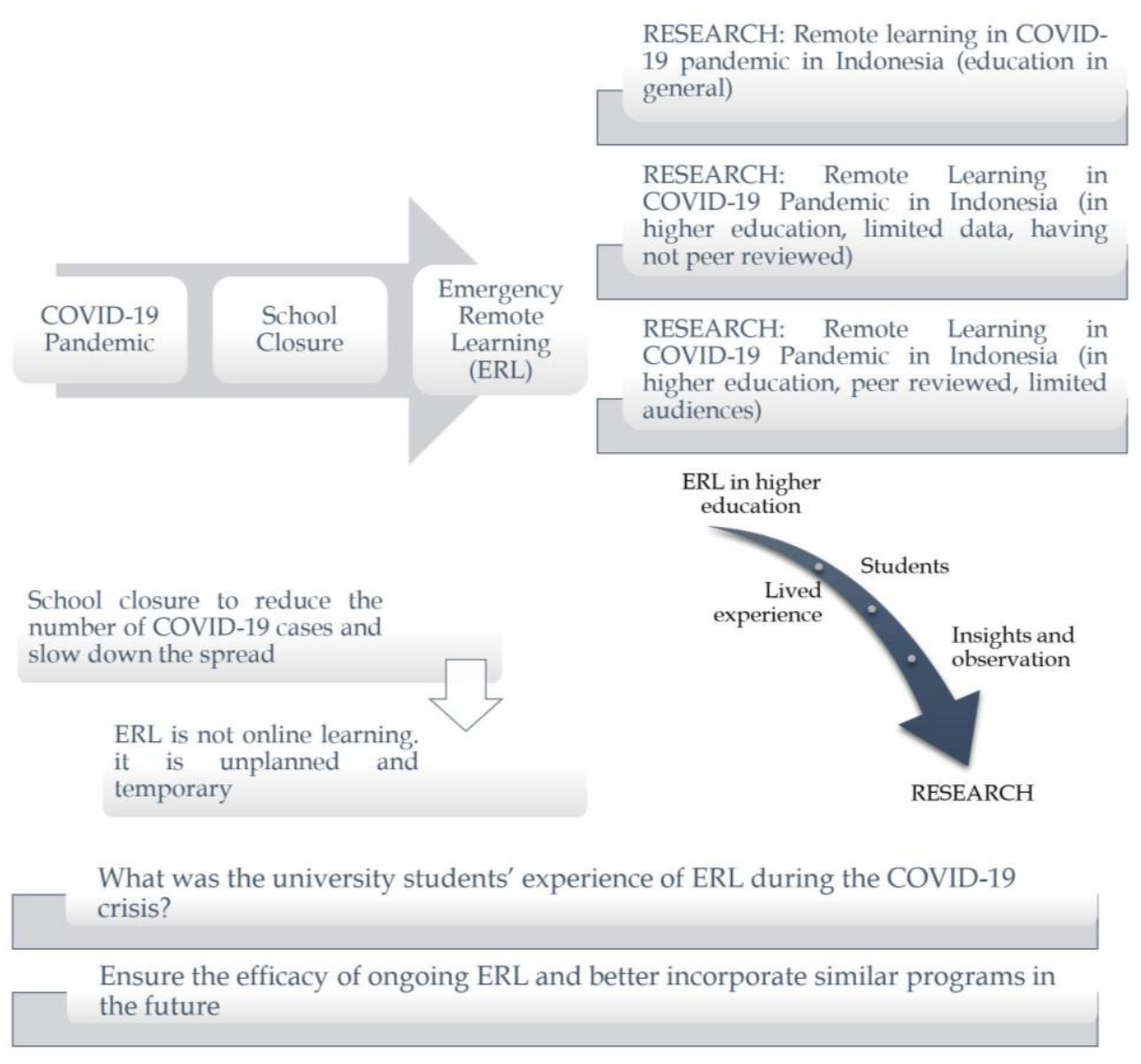

Figure 1. Theoretical Model

The theoretical model outlined in Figure 1 shows what the related studies have been performed, what this study was intended to do, and the research questions raised by the context analysis and previous research. Recent studies have described school closure as one of the key components of a range of nonpharmaceutical prevention approaches aimed at minimizing the number of cases and preventing the spread of disease. Some of the previous emergency remote learning studies concluded that ERL is a temporary learning mechanism, a transition from in-person instruction to substitute delivery due to an emergency. Nonetheless, little is known on how to apply remote learning in higher education during the outbreak of COVID-19 and how students perceived and experienced ERL implementation.

Research on the implementation of home learning during COVID-19 in Indonesia has been listed above. None of those papers use the term remote learning or ERL. The use of the term affects the analysis and understanding that is predicated in these studies. It is crucial to make a distinction, as the term refers to a unique and specific event (Manfuso, 2020). This research filled the gap in knowledge (theory) of ERL at the university level in Indonesia with insights and observations collected from students who had been studying from home for an extended period (more than ten weeks), had undergone an online mid-term exam, and was at the end of the semester. Other than that, this research disseminated its findings in English articles in international journals, so that more audiences could read and learn from the research findings. 
This research also filled the practical gap on how to successfully implement ERL in higher education to meet learners' needs. This study's main question is: how university students experienced ERL due to the COVID-19 crisis? Through knowing how university students learned in the emergency COVID-19, we could improve on in-going practice. The students' feedback is also critical to improve the learning process in the future if such a situation was ever to occur again. It is unknown how long ERL will continue or what kind of other problems we may face in the future, so educational institutions and students alike must be better prepared for any such eventuality.

\section{Materials and Methods}

The current study is presented as part of a larger project on ERL in tertiary education in Indonesia during the COVID-19 outbreak. The overall aim of the study was to explore the implementation of ERL in tertiary education in Indonesia. The study employed a qualitative method of the phenomenological approach. This phenomenological analysis aims to collect and examine the lived experience of university students who have learned from home, due to the COVID-19 crisis, for more than two months. These experiences provided a new level of insight into ERL's implementation due to the outbreak of COVID-19.

A phenomenology is a philosophical approach to the analysis of phenomena that are part of human awareness (Arbnor \& Bjerke, 2011). In phenomenology, the researcher attempts to provide a direct description of someone's experience as it is, without considering his or her psychological origin and the causal explanations that the scientist may be able to provide (Merleau-Ponty \& Landes, 2013). Phenomenology is equipped to understand the subjective interpretations of the participants of the fundamental object of the study by throwing light on the significance applied to their lived experience and exploring the specific meanings underlying the empiric variants of a given phenomenon rather than merely applying the technique (Casmir, 1983; MacDermott, 2002).

Participants in this research are 80 students who have studied social science education at a public university in Jakarta. The researcher employed a purposive sampling method to select the participants. The researcher understood the purpose of the study in such a way that she relied on her judgment to classify qualified participants in a particular profile. The various explanations why the researcher chose the participants are as follows: the first reason was the ease of access for the researcher to collect data due to the COVID-19 situation, which restricted the researcher's ability to gather data. The second reason, they were semester four students, which means that they were in the middle of their course (undergraduate education usually takes eight semesters). These students already have enough learning experience and were still taking compulsory and additional courses (semester seven students practice teaching, and in semester eight, write a thesis). Third, students at this university come from Jakarta and other provinces and different backgrounds. This diversity will help enrich the data further. Lastly, the researcher intentionally chose students from educational programs because they were prepared to become teachers, and their opinions are important because their answers address how an educator should teach at a time like this. 
These students are in the fourth semester and came from two classes, $4 \mathrm{~A}$ and $4 \mathrm{~B}$. These two groups have different concentrations, $4 \mathrm{~A}$ is Sociology, and $4 \mathrm{~B}$ is Geography. The name of the university and the names of the students have been hidden; to protect the identity of the participants and to provide them with the opportunity to speak freely. Participants were aware of the scope and intent of the study, and they were allowed to withdraw from the research anytime they chose if they felt dissatisfied with it.

Data collection was carried out using creative methods because the researcher was unable to conduct direct interviews due to the large-scale social restrictions that were in place during the research period, data collection was completed by asking participants to write a diary of their daily learning activities for two weeks (4 - 18 May 2020. See Appendix 1. Students' Diary). They were then asked to compose a reflective essay about ERL (collected on May 20, 2020. See Appendix 2. Reflective Essay).

The researcher paid close attention to data triangulation to develop a comprehensive understanding of the phenomena. Therefore, the researcher used multiple methods or data sources, as suggested by Patton (Patton, 1999). The data source utilized, other than diaries and essays, was focus group discussions using the Google Meet application. These discussions were conducted twice; each meeting was for 120 minutes and 40 participants (on May 26 and 27, 2020). The focus group discussions were also aimed as a member check to increase the precision, reliability, validity, and transferability of the findings. The researcher presented the study's overall findings and then opened a discussion session. Participants were free to question if any incorrect information had been recorded and were allowed to add or remove details. The participants either confirmed that the summaries represented their beliefs, feelings, and experiences or did not reflect their experiences. The researcher concluded that the study seems credible after the participants confirmed the accuracy and completeness of the study.

The complete elimination of non-response bias from the study is impossible. Mixing data collection methods was one of the researchers' efforts to avoid nonresponse impact from the sample. The researcher also sought to eliminate bias by designing strategies that would promote the involvement of selected individuals.

The researcher used the NVivo program for data management and analysis. NVivo is useful in organizing data and helped the researcher make sense of it throughout the research since the data for this qualitative research was extensive (80 participants). The researcher also made a memo in the NVivo system that allowed for the possibility to document ideas and analyze thoughts, perspectives, and observations of students on online learning. This analytical memo was completed on an ongoing basis, every time data (journal or essay) was submitted. Analytical memos provide a means for the researcher to record their thoughts during the research process and to code memos as additional data for the study (Saldaña, 2016).

In analyzing the data, the researcher adopted a two-stage coding model conducted by Miles, Huberman and Saldaña (Miles et al., 2014) and Saldaña (Saldana, 2009; Saldaña, 2016). The first cycle coding was initially assigned to the 
data, followed by the second cycle codes in which the initial codes were grouped into meaningful categories, themes, or constructs. The two stages of coding are not a single linear event; the qualitative analytical process is cyclical. In practice, in the first cycle, the researcher coded each essay and journal individually. After that, the researcher compared the data and detailed the code into a sub-code if necessary. In the second cycle, the researcher reorganized and re-analyzed the data coded in the first coding cycle. The primary aim of second-cycle coding was to establish a sense of categorical, thematic, conceptual, and theoretical structure from the first-cycle code series. The researcher changed codes, added new codes, and dropped a few codes to conclude themes of research findings. Finally, the researcher made the summative synthesis assumptions and declarative claims. The assertions are based on the researcher's insights and observations, supported by evidence from the data corpus.

\section{Results}

How did university students experience ERL during the COVID-19 crisis? Results revealed that students' experiences fell into two overarching themes, each with related sub-themes. The two identified themes and subthemes are: (a) blended learning, with the subthemes of e-learning, m-learning, and conventional learning, and (b) paradoxical learning, with the sub-themes of flexible learning and challenging learning.

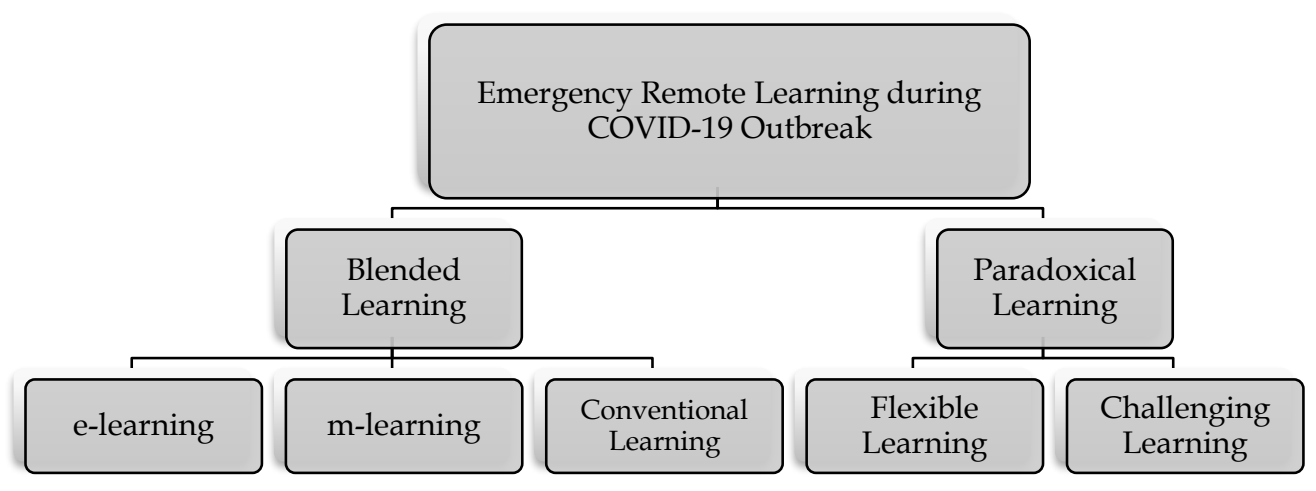

Figure 2. Research findings

The researcher classified 25 codes, in the first cycle coding, from the data gathered from 80 diaries, 80 reflective essays, and two focus group discussions. The researcher then grouped related codes into five groups, which included: elearning, m-learning, traditional learning, flexible learning, and challenging learning. The researcher summarized two key themes of this study's results in this second coding process: blended learning and paradoxical learning. The researcher concluded that during ERL, students experienced blended learning approaches, and their experiences were paradoxical. They enjoyed learning from home, but also saw it as challenging too. The following is an illustration of the process of codification, thematic discovery, and the construction of assertions. 

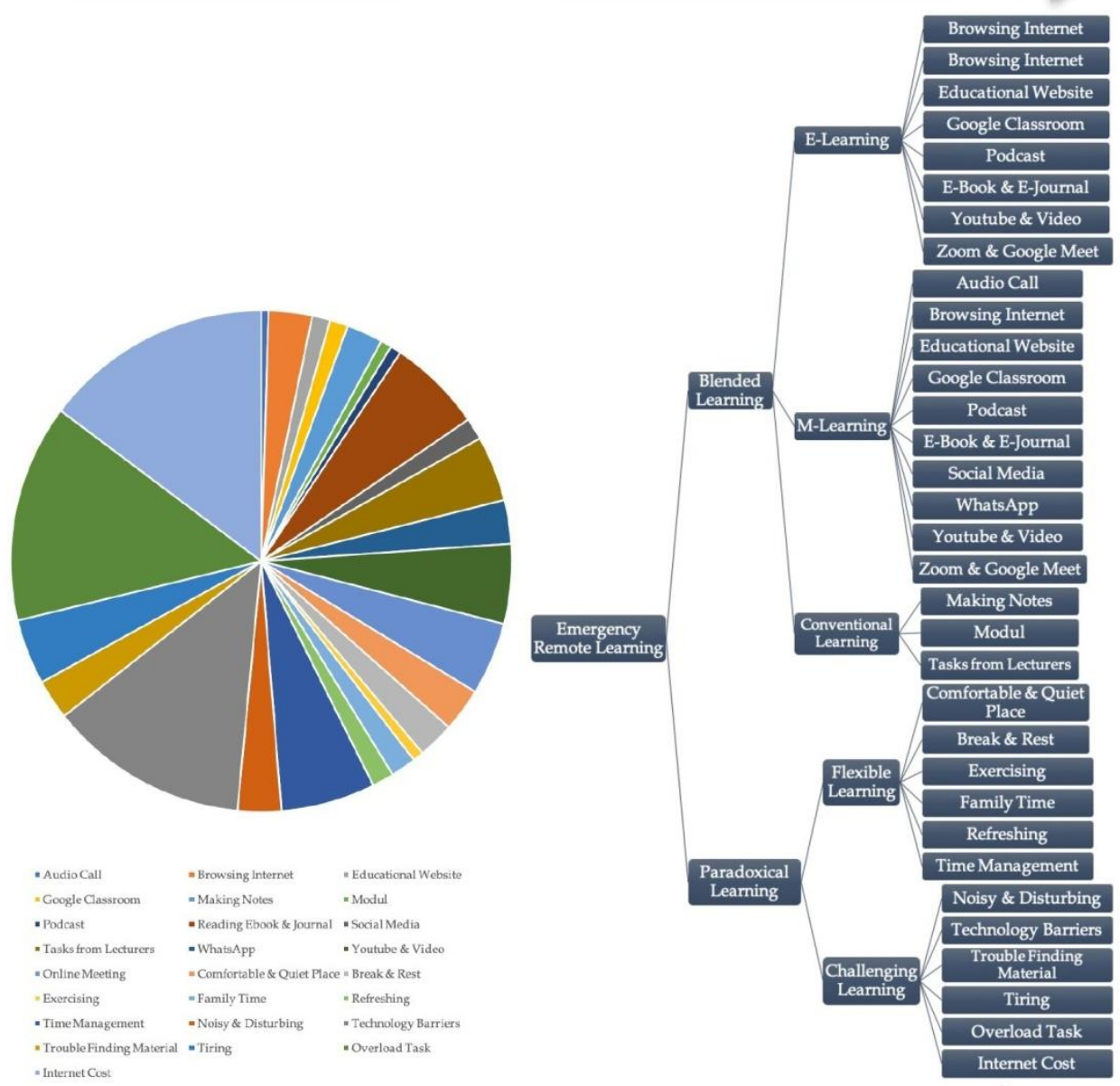

Internet $\mathrm{Cos}$

\section{Analystic Memoing}

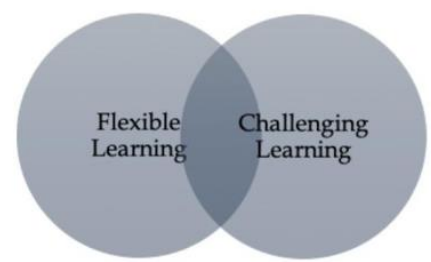

Paradoxical Learning

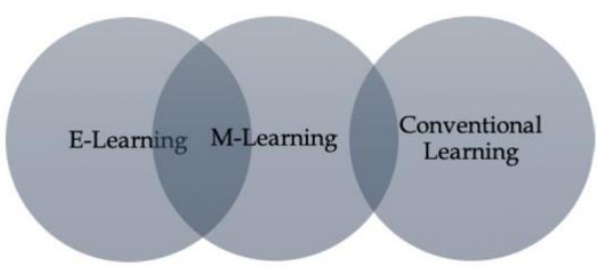

Blended Learning

Students experienced remote emergency learning using a blended learning model and see learning as paradoxical.

Figure 3. Data analysis process 


\subsection{Blended Learning}

Of the twenty-five codes found in the first coding cycle (as shown in Figure 2 above), thirteen are related to the media or methods used during the ERL. The researcher then grouped codes that show similar meaning in categories: elearning, m-learning, and conventional learning. The researcher concluded from the categories that learning remotely during the COVID-19 situation involved a mix of technological learning media and conventional methods, or using blended materials.

Table 2. Learning media/methods \& frequency of being mentioned by participants

\begin{tabular}{|l|c|c|}
\hline \multicolumn{1}{|c|}{ Media/Methods } & Frequency & Categories \\
\hline Reading E-book \& E-Journal & 56 & e-learning \& m-learning \\
\hline YouTube \& Video & 52 & e-learning \& m-learning \\
\hline Online Meeting (Zoom or Google Meet) & 50 & e-learning \& m-learning \\
\hline Browsing Internet & 42 & e-learning \& m-learning \\
\hline Educational Website & 35 & e-learning \& m-learning \\
\hline Podcast & 33 & e-learning \& m-learning \\
\hline Google Classroom & 35 & e-learning \\
\hline WhatsApp & 42 & m-learning \\
\hline Social Media & 36 & m-learning \\
\hline Audio Call & 32 & m-learning \\
\hline $\begin{array}{l}\text { Assignments from Lecturers (exercises, } \\
\text { quizzes, and exams) }\end{array}$ & 58 & Conventional Learning \\
\hline Making Notes & 40 & Conventional Learning \\
\hline Module/Unit & 33 & Conventional Learning \\
\hline
\end{tabular}

From the coding of the data in the NVivo program, researchers have discovered how many frequencies a single code of all the existing data appears. Table 2 shows which media or methods are most mentioned repeatedly by students.

Reading e-books and e-journals was the most common learning methods experienced by the students. Students also learned from YouTube and TV series or movie documentaries. Usually, lecturers provided students with YouTube links, asked them to study the video, and make a summary report. E-Books, EJournals, and YouTube videos were used to help explain learning about the subject or giving instructions. Other platforms used to deliver the lecturers' instructions or explanations were through WhatsApp (the lecturer recorded voice notes and shared them in the WhatsApp group) and through the module or unit of work being studied. 
Three platforms were commonly used for classroom discussions: online meetings in Zoom or Google Meet, WhatsApp, and Social Media. They interchangeably used the term Social Media for WhatsApp also, while a few referred to Facebook when mentioning about Social Media. Not all the lecturers arranged synchronous discussions using online platforms. Many students complained about it; they felt that learning was ineffective without discussion. WhatsApp was the most preferred media for discussion. In WhatsApp, the discussion could be synchronous or asynchronous. The discussion could be made using either voice notes or texts.

In order to enrich learning, students have tried to browse for more reading material online by searching the internet and by visiting educational websites. If they did not understand the subject, they would invariably contact their classmates, asking them to explain the subject. The respondents believe that YouTube videos are a good source of learning. Some listened to podcasts and explained that this was as a result of needing to be more creative in expanding their understanding. In measuring student learning progress, lecturers have delivered assignments and quizzes to students through WhatsApp and Google Classroom. Also, conventional methods were used for evaluation. The most common conventional tasks assigned to students are the memorization of texts and the writing of a summary.

The data reveals that emergency remote learning has not always been entirely conducted online using sophisticated information technology; students have often learned using conventional media and methods. The students take notes, use paper, and pens to help them understand learning materials more efficiently. They took notes on the video, sound recordings, e-books, PowerPoint presentations, and journals provided by the lecturers. They felt that, in general, they had not learned anything if they did not write it in a book. They seemed to be able to understand more quickly when they wrote down what they had learned in a notebook. Participant 4B24 explained about making a summary of learning using paper and colorful pens and markers:

"If the lecturer has given material in the form of power points, modules, and so on. I put together a summary of the material. And if there was a discussion on WhatsApp or Zoom, I try to write notes about things that I thought were important. Just like the previous way of learning (before the COVID-19 crisis), I used colored pens or markers to write notes, so I wouldn't get bored while reading notes." (4B24)

Whereas 4B35 said that she had made a mind map of the content she had learned in order to be able to pass the mid-term and final exam. She added that she placed her notes on the wall, and every morning she memorized and learned them:

"Although the mid-term test and end semester exams will be done online, I will still make a mind map to test my understanding of the material... for the final exam, I will make keywords from each material that I have studied, I will make notes in my paper and paste them on the wall, and every morning I will memorize and learn." (4B35)

Students also conventionally learnt using modules or units, not a printed version, but an e-module in PDF format. Two lecturers provided these e-modules 
containing discussions, quizzes, and a summary. The aim was to help students learn independently. They can test their comprehension by answering the quiz in the module and checking its accuracy by matching the answer key on the last page of the module. The lecturers shared the module every 1-2 weeks. Some students printed the modules or made a hand-written summary of the modules. The students also explained that they felt more like they had studied when they have paper, pen, and writing in a book.

"In the pandemic from the COVID-19 crisis, my learning is using modules or PowerPoint presentations that I have obtained from lecturers or notes from my colleagues." (4C27)

"I try to understand the tasks or modules provided, read all through them, yet I still don't get it." (4C30)

Another conventional learning method is lecturers giving students assignments. Students complained they actually had to finish too many assignments.

"Lecturers have been giving assignments online, a lot of them. Some lecturers only give assignments continuously." (4B21)

In ERL, blended learning was used for instruction and explanation, discussion, evaluation, and enrichment. The researcher mapped out the thirteen media/learning methods mentioned by the students in diaries and essays and the purpose of their use. Here is the following map:

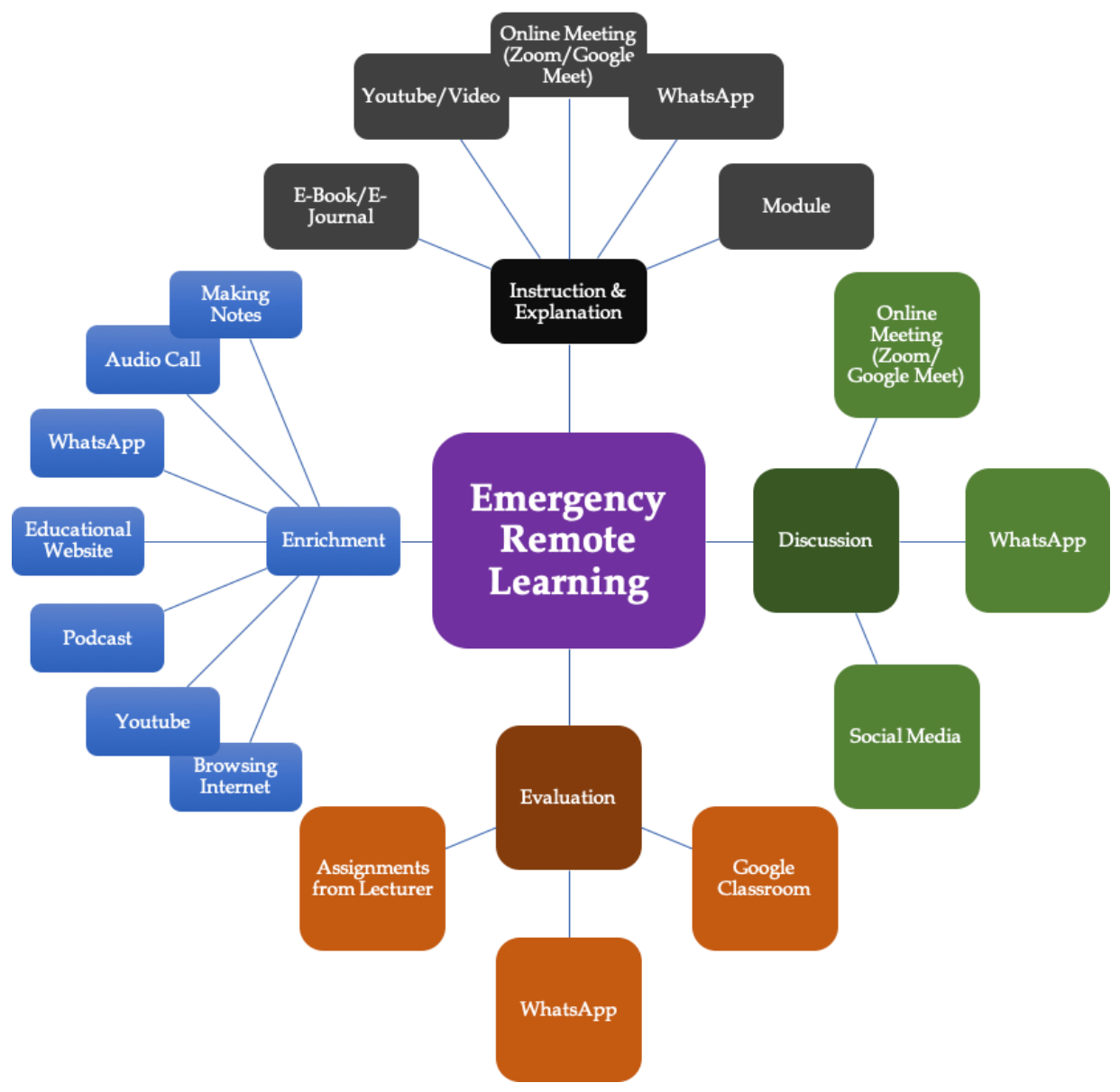

Figure 4. Blended media in ERL and their purpose of use 
WhatsApp is a prevalent medium used for all these learning purposes. WhatsApp is used to explain, discuss, evaluate and enhance learning. In addition, WhatsApp is also used for almost all courses during the ERL period. Only one of the eight courses in Class $4 \mathrm{~A}$ and Class $4 \mathrm{C}$ did not use the WhatsApp. This assertion is derived from tabulations made on the types of learning platforms used for each subject.

Table 3. Courses and learning platforms

\begin{tabular}{|c|c|c|c|c|}
\hline \multirow[t]{2}{*}{ No } & \multicolumn{2}{|c|}{ CLASS 4A } & \multicolumn{2}{|r|}{ CLASS 4B } \\
\hline & COURSES & $\begin{array}{l}\text { LEARNING } \\
\text { PLATFORMS }\end{array}$ & COURSES & $\begin{array}{l}\text { LEARNING } \\
\text { PLATFORMS }\end{array}$ \\
\hline 1. & $\begin{array}{l}\text { The New } \\
\text { Indonesian } \\
\text { History }\end{array}$ & $\begin{array}{l}\text { - YouTube } \\
\text { - Assignment via } \\
\text { WhatsApp } \\
\text { - Assignment via } \\
\text { Email }\end{array}$ & $\begin{array}{l}\text { The New } \\
\text { Indonesian } \\
\text { History }\end{array}$ & $\begin{array}{ll}\text { - } & \text { YouTube } \\
\text { - } & \text { Assignment } \\
\text { WhatsApp } \\
\text { - Assignment } \\
\text { Email }\end{array}$ \\
\hline 2. & $\begin{array}{l}\text { Study } \\
\text { Learning }\end{array}$ & $\begin{array}{l}\text { - Google Classroom } \\
\text { - YouTube } \\
\text { - Google Meet } \\
\text { - WhatsApp } \\
\end{array}$ & $\begin{array}{l}\text { Study } \quad \& \\
\text { Learning }\end{array}$ & 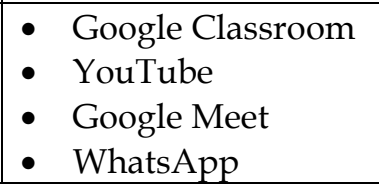 \\
\hline 3. & $\begin{array}{l}\text { Educa } \\
\text { Psych }\end{array}$ & $\begin{array}{l}\text { - Module } \\
\text { - Email } \\
\text { - Google Meet }\end{array}$ & $\begin{array}{l}\text { Edu } \\
\text { Psy }\end{array}$ & $\begin{array}{ll}\text { - } & \text { Module } \\
\text { - } & \text { Email } \\
\text { - } & \text { Google Meet } \\
\end{array}$ \\
\hline 4. & $\begin{array}{l}\text { Regional } \\
\text { Geography of } \\
\text { the World }\end{array}$ & $\begin{array}{l}\text { - Reading Material } \\
\text { - Academic } \\
\text { Instruction System } \\
\text { - WhatsApp } \\
\end{array}$ & $\begin{array}{l}\text { Regional } \\
\text { Geography of } \\
\text { the World }\end{array}$ & $\begin{array}{l}\text { - Reading Material } \\
\text { - Academic } \\
\text { Instruction System } \\
\text { - WhatsApp } \\
\end{array}$ \\
\hline 5. & $\begin{array}{l}\text { Learning } \\
\text { Strategies }\end{array}$ & $\begin{array}{l}\text { - Assignment } \\
\text { - Google Classroom } \\
\text { - WhatsApp }\end{array}$ & $\begin{array}{l}\text { Learning } \\
\text { Strategies } \\
\text { Google } \\
\text { Classroom } \\
\text { WhatsApp } \\
\end{array}$ & $\begin{array}{l}\text { - Assignment } \\
\text { - Google Classroom } \\
\text { - WhatsApp }\end{array}$ \\
\hline 6. & $\begin{array}{l}\text { Practicum } \\
\text { Reading the } \\
\text { Quran }\end{array}$ & $\begin{array}{l}\text { - Assignment } \\
\text { - WhatsApp Email }\end{array}$ & $\begin{array}{l}\text { Practicum } \\
\text { Reading the } \\
\text { Quran }\end{array}$ & $\begin{array}{l}\text { - Assignment } \\
\text { - WhatsApp Email }\end{array}$ \\
\hline 7. & $\begin{array}{l}\text { Entrepreneurs } \\
\text { hip }\end{array}$ & $\begin{array}{l}\text { - Google Scholar } \\
\text { - WhatsApp Group } \\
\text { - Voice note }\end{array}$ & $\begin{array}{l}\text { Entrepreneur } \\
\text { ship }\end{array}$ & $\begin{array}{ll}\text { - } & \text { Google Scholar } \\
\text { - WhatsApp Group } \\
\text { - Voice note }\end{array}$ \\
\hline 8. & $\begin{array}{l}\text { Sociology } \\
\text { Religion }\end{array}$ & $\begin{array}{ll}\text { - } & \text { Email } \\
\text { - Voice Note } \\
\text { - WhatsApp } \\
\text { - } \text { PowerPoint } \\
\text { Presentation } \\
\end{array}$ & Cartography & $\begin{array}{ll}\text { - } & \text { Lecturing in Zoom } \\
& \text { Meeting } \\
\text { - } & \text { Google Meet } \\
\text { - } & \text { Assignment } \\
\text { - } & \text { WhatsApp } \\
\end{array}$ \\
\hline
\end{tabular}

During the semester, students from class $4 \mathrm{~A}$ and $4 \mathrm{~B}$ studied eight courses, seven of which were the same for both classes and taught by the same lecturers. The seven courses taught in Class 4A and Class 4B were: New Indonesian History, Study and Learning; Educational Psychology; Regional Geography of the World; Learning Strategies; Practicum Reading the Quran; and Entrepreneurship. The distinctions were: Class 4A took Sociology of Religion, and Class 4A took Cartography. 


\subsection{Paradoxical Learning}

The second main theme of the findings is "paradoxical learning." The researcher used this concept to describe how students had paradoxical perspectives and insights into learning. On the one hand, they saw ERL as flexible, but on the other hand, they also saw it as challenging.

Table 4. Students' insights \& observations on Paradoxical Learning

\begin{tabular}{|l|c|l|}
\hline \multicolumn{1}{|c|}{ Insights/Observations } & Frequency & \multicolumn{1}{c|}{ Reasons } \\
\hline Time Management (Flexibility) & 83 & Flexible Learning \\
\hline Family Time & 52 & Flexible Learning \\
\hline Exercising & 51 & Flexible Learning \\
\hline Comfortable \& Quiet Place & 42 & Flexible Learning \\
\hline Break \& Rest & 40 & Flexible Learning \\
\hline Refreshing & 36 & Flexible Learning \\
\hline Technology Barriers & 85 & Challenging Learning \\
\hline Cost of Internet & 83 & Challenging Learning \\
\hline Overload Assignments & 73 & Challenging Learning \\
\hline Trouble Finding Materials & 51 & Challenging Learning \\
\hline Tiring & 49 & Challenging Learning \\
\hline Noisy \& Disturbing & 42 & Challenging Learning \\
\hline
\end{tabular}

Table 4, we can see how many times students reported certain insights or observations about ERL paradoxically of all the existing data. The researcher used color codes to show how they saw learning as two polar opposite scales. The twoyellow color coded cells are time management and overload tasks. The threeorange color coded cells are family time, comfortable and quiet, and noisy and disturbing. The three-green coded cells are exercising, break and rest, and are tiring. Four-blue coded cells are refreshing, technology barriers, internet costs, and trouble finding materials. The segregated color-coded data indicates how students had paradoxical perspectives and insights into learning.

On the one hand, students saw ERL as flexible; on the other hand, they also saw it as challenging.

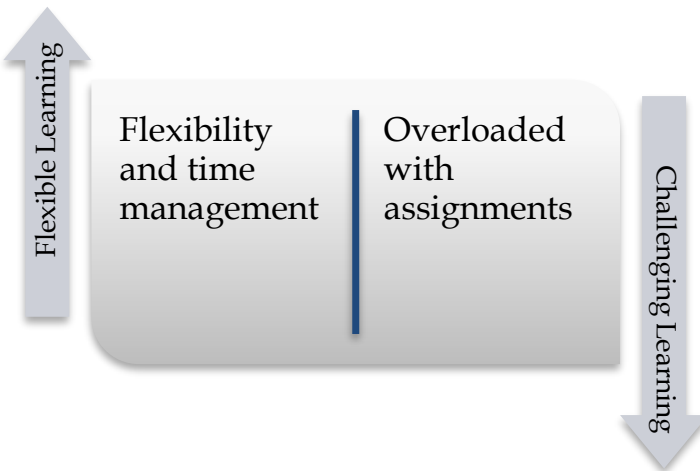

Figure 5. Flexibility versus overloaded 
Students said that learning remotely at home gave them the flexibility to manage their time.

"The flexible learning schedule matches our lifestyle; young people. Lecturers and students are increasingly turning to online learning as a viable alternative to study anywhere, anytime." (4B26)

Contradictory to the amount of flexibility, they also argued that the lecturers overloaded them with assignments, and they, therefore, found it difficult to manage their time.

"It's not necessarily online learning or lectures that we were given, but now there are remote assignments (online). And the tasks that were given never stopped every week, we were given assignments by each subject, and we were chased by deadlines. In my view, it can make students frustrated and depressed. As we now know that we need to retain our body's immunity to avoid the virus, and the stress or pressure caused by the assignments may, in my opinion, disrupt the students' immunity from the body." (4C33)

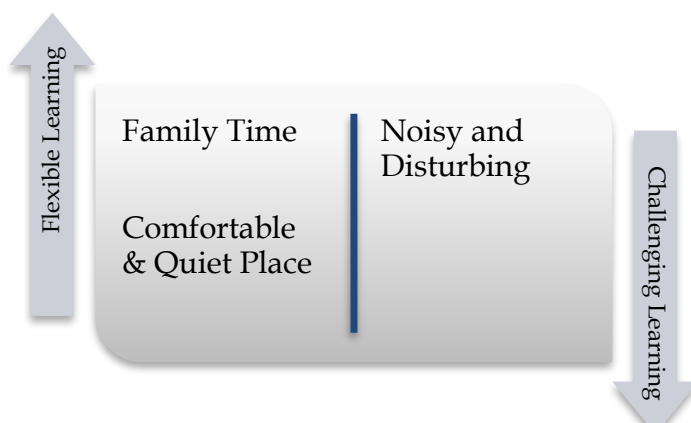

Figure 6. Family time, comfortable \& Quiet versus noisy \& disturbing

The students said that during remote learning, they have a lot of family time and could study in a comfortable and quiet place.

"Studying online makes it easy for us to find places that make it easier to think about, such as open spaces, indoor rooms, and family rooms at home." (4B17)

In contrast to this, they also felt disturbed by their siblings and the noise at home.

"The home environment cannot be controlled when there is a live lecture that uses applications such as Google Meet and synchronous conversation. The situation of the house is crowded. It's very annoying, in my opinion, and it makes me unable to focus." (4B18) 


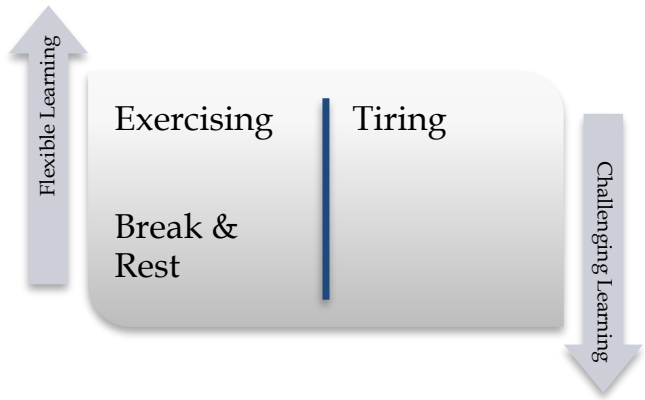

Figure 7. Exercising, break \& rest versus tiring

Some students did some regular exercise at home. They spared extra time for selfcare.

"If there are no assignments, I will take the time to exercise and bask in the healthy morning sun." (4B28)

"After I wake up, I do regular exercise or aerobic exercise. I' $m$ doing this regularly. Learning from home allows me to exercise more." (4C38)

Because the students were staying at home, they were able to take a break during learning. They did not want to push themselves too hard to study. Their main focus was to keep healthy and not be too tired.

"In addition, I also tried not to be too tired and forced to study because of the consequences of the Covid-19 pandemic, I had to be careful not to fall ill. I also don't push myself too much when I'm tired of studying." (4B15)

Other respondents, however, felt that compared to face-to-face learning, remote was much more tiring.

"I want to complain that this distance learning is very ineffective and makes me even more exhausted." (4C20)

"A lot of tasks! The lecturer should consider the fact that a student is staying at home to avoid illness or infection from happening. The lecturer gave us lots of assignments excessively. It kills us. Not because of the coronavirus that causes us to die. May Allah Amen protect us." (4C18)

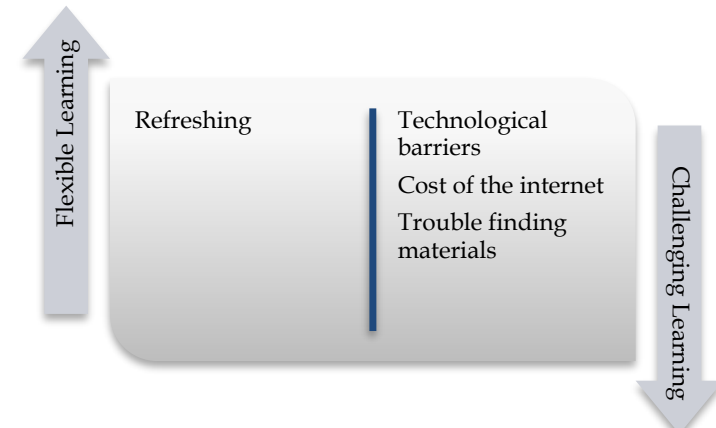

Figure 8. Refreshing versus problems 
The students said they tried to manage their time and refresh themselves whenever they were tired. They said this is what made learning from home more flexible.

"Learning activities must be interspersed with activities that are fun, refreshing. In order not to be boring, I always prepare fun activities (in my opinion). This activity can also be a reward or reward when I have completed an assignment or studied material." (4C21)

They also complained, however, about technological disruption while studying, expensive internet costs and difficulties in obtaining learning materials during the ERL.

"The difficulty of accessing the Internet, I was at home during this distance learning process. This makes me experience delays in getting information because access to the Internet in the village is a bit difficult, the internet connection is bad in my area." (4B18)

"It's very pricey to spend money on the internet data plan. I'm a student who gets minimal pocket money, especially on staying at home like this, I don't get any income from being a Scoutmaster. That makes it hard for me to buy a data plan. I' $m$ also envious of campuses that provide a free data plan of up to 150 thousand rupiahs per month." (4B12)

"This policy has a side where I don't like it, for example, because I can't go anywhere, so I have trouble finding references that I need to complete my assignments. Learning resources are also limited and can only refer to the internet and journals that aren't always right" (4B19).

\section{Discussion}

Indonesia reported the first two confirmed cases of COVID-19 in a Jakarta suburb on March 2, 2020 (World Health Organization, 2020a). The situation became increasingly dangerous in mid-March. President Jokowi, in a press conference at the Bogor Presidential Palace on Sunday, March 15, 2020, called on local governments to issue policies to prevent the spread of the coronavirus. One of the policies recommended was to temporarily halt teaching and learning in schools and universities and encourage students to study at home. As a follow-up to the president's direction, on March 20, 2020, the Minister of Education and Culture issued a Circular Number 36962/MPK.A/HK/2020 concerning online learning and working from home in the context of the prevention of coronary disease spread. Following this rule, the campus, which was the focus of this research, began to close on March 23, 2020.

Learning was suddenly moved to remote learning. Remote learning has not been anticipated, and most of the course syllabus was not designed to be an online or for a distance learning experience. Without preparation or training, lecturers designed and implemented remote learning programs. Similarly, students did not have the opportunity to be prepared for this transition in learning. Despite all of these limitations, everybody has been trying their best to make the situation a success, quick and reliable temporary access to education in unprecedented time. 
Lecturers began using the media or the methods they were familiar with and comfortable using. It may not be perfect, but students are resilient, the educator is resourceful, and everyone has to make the most of what they have (Juliani, 2020). This study reveals that learning remotely during the COVID-19 situation involved a mix of both conventional and non-conventional methods. Technological learning media was used combined with pen and paper methods. The use of blended materials is what the researcher concluded as the first theme.

Blended learning is the application of more than one method, strategy, technique, or media in education (Sadeghi et al., 2014; Thiele, 2003). It is a mixture of conventional lectures or tutorials and web-based material (Concannon et al., 2005); when delivering information, traditional face-to-face learning is combined with technology (Farrel, 2006). In line with the government's policy of social distancing, learning has taken place at home. Teachers and students separated by physical distance but connected through technology, equipment, and resources. Nonetheless, the data indicate that learning was not entirely online; students were still studying in conventional ways. Conventional here does not mean that there have been face-to-face lectures, but conventional learning methods for taking notes, summarizing learning and memorizing notes.

In this study, the researcher distinguished between e-learning and m-learning based on the devices used. E-learning means that the educational model used is based on the use of electronic media and devices as tools for improving the availability of training, communication, and interaction, and that helps to accept new ways of understanding and learning (Salloum et al., 2019). An essential element of e-learning is the use of electronic media, and e-learning is currently explained as learning that is used through various computer devices, such as computers, mobile phones, tablets, and virtual environments. M-learning focuses on learning mobility, engagement with portable technology, and learning that represents an emphasis on how society and its institutions could accommodate and sustain an increasingly mobile population (Mehdipour \& Zerehkafi, 2013). By using mobile apps, learners can learn anywhere and anytime (Crescente \& Lee, 2011). In Indonesia, internet users have reached 150 million people, with a 56 percent penetration spread across the region. There is only a small difference with the number of mobile internet users, which amounts to 142.8 million people, with a penetration percentage of 53 percent (Ministry of Communication and Information Technology Republic of Indonesia, 2020). So, most people are linked to the internet through mobile phones. Many homes do not have laptops or PCs, but they are still connected online using mobile devices. The distinction between e-learning and m-learning clarifies this phenomenon. In case of emergencies, remote learning students have explained that they are connected using mobile devices or tethered from a cell phone when they need to work from a laptop.

Blended learning is supposed to make learning more efficient by integrating technology-based learning with traditional style learning. Some research has identified many benefits of blended learning. Many studies have been carried out to compare conventional teaching methods with blended learning, and different results have been obtained. In some research, the participants' test scores did not differ between the two groups (Khan, 2001). Thiele's study showed that the 
student knowledge scores in the blended teaching method were higher than the lecturing method, but that the difference was not statistically significant (Thiele, 2003). Sedeghi et al. contrasted students' learning and satisfaction with teaching and e-learning with traditional teaching methods. The results showed that the blended method is effective in increasing the student learning rate (Sadeghi et al., 2014). McPhee and Pickern (2017) concluded how ICT could help international students' learning experience. Kirkwood (2009) claimed that ICT could make doable learning tasks or situations that would otherwise be extremely difficult to achieve and encourage an incremental improvement in learning outcomes. Stephenson, Brown, and Griffin (Stephenson et al., 2008) argued that most elearning seemed to mimic or complement established academic practices, mainly when used in 'blended' contexts. Another study suggests that a combination of face-to-face training with e-learning is more flexible than other methods (Garrison \& Kanuka, 2004).

This ERL might not have been the ideal one. Blended learning has been questioned as to the best solution to studying during the pandemic when universities are closed. The advantages of blended learning described in the studies, as mentioned above, are in contrast to the experience of students. Afterward, we must remember that this blended learning took place in an emergency with limited resources. As highlighted in the introduction, the researcher refers to it as "emergency remote learning," not just "remote learning" using blended materials. Before COVID-19, the classes studied by the researcher rarely used e-learning and m-learning. E-learning and m-learning have emerged as one of the alternatives to the problems of education during an outbreak of coronavirus. E-learning and m-learning offer expanded opportunities for learning versatility when students and educators are under the stay-at-home order. However, there were challenges in using technology in learning. Students talked about the technical barriers that hindered their learning due to technical problems or the inability to use technological resources.

Students also discussed the shift in learning styles. Students were already accustomed to face-to-face conventional teaching approaches. They claimed in their writings that they felt that they were not learning since there was no lecturer to guide them to understand the lesson. E-learning and m-learning involve students working interdependently, in groups or independently to solve problems, to work on projects, to meet individual needs, and to encourage students to speak and choose. Students complained about this kind of independent learning, doing assignments, and reading on their own. They were familiar with the teaching-learning model, where lecturers gave learning materials; students listened and took notes.

Another thing to think about is the availability of learning resources in Bahasa Indonesia. Students said that they have trouble getting learning materials since the libraries are closed. Universities have no access to paid online journals. So, students are only using open-access materials.

The findings of this study reveal that university and its community were not well prepared to face an emergency, such as the closure of the campus due to a pandemic. Courses designed for conventional learning, the unusual use of 
technology in teaching and learning programs, students were not able to study independently, limited access to learning materials in the native language of learners, and lack access to high-quality reading resources (e.g., paid e-journals and e-books). All of these issues need to be highlighted and addressed. Now and in the future, the university should be more involved in information communication technology. University learning should encourage students to learn independently through a wide range of methods and media. Resources for remote learning need to be strengthened, and students should get more access to reading materials

Another theme that arose from this study is ERL during the outbreak of COVID19 is paradoxical. Paradoxical, according to the Cambridge dictionary 2020), is, "Seeming impossible or difficult to understand because of containing two opposite facts or characteristics." If something is paradoxical, it involves two facts or qualities that seem to contradict each other (Collins Dictionary, 2020). The university moved in-classroom-learning to online-based learning without enough preparation. This rapid change was a test of organizational agility $(\mathrm{Wu}, 2020)$. Students and lecturers were still adapting and looking for ways of teaching and learning that were much better and easier. Educational planning in times of crisis needs creative problem solving (Hodges et al., 2020). ERL needs much hard work, but this is the only way forward. After some time, it is essential to review, develop the current practice, and plan for future programs.

Learning from home might continue in the next few months, and this emergency could happen again in the future. What are we supposed to do to make the ERL better? Bao (2020) observed online teaching during the outbreak of COVID-19. Bao has identified six educational strategies to improve student concentration and engagement to achieve a smooth transition to online learning:

1. Preparing emergency preparedness plans for unexpected problems. If the teaching plan A is not working because of a technical problem, try Plan B, C, or any other plan.

2. Distributing the teaching content into smaller units to help the student focus. The lecturers should divide the teaching content into several small modules lasting approximately 20-25 minutes.

3. Emphasizing the use of "voice" in online teaching. Body language and facial expressions are restricted in online instruction, and only the "voice" is entirely functional. Therefore, in online teaching, the faculty should properly slow down its speech to allow students to capture critical knowledge points.

4. Working with teaching assistants and get online help from them. This arrangement is also missing from the students' courses in this research. There are no teaching assistants for the lecturers. Online teaching includes the technology and professional expertise of those involved. Most faculties at universities in Indonesia are not sufficiently trained or equipped to operate online educational platforms, and support from teaching assistants is especially relevant.

5. Strengthening the students' ability to learn outside the classroom. The faculty has less control over online teaching. As a result, the progress of 
online teaching and its learning efficiency depends mainly on high-level active learning outside the classroom. To this end, the faculty should use various methods to moderately modify students' homework and reading requirements to strengthen students' active learning outside the classroom. Students complained about assignments in this research. Lecturers and students need a dialogue to address what is currently expected and should be achieved by two parties, students and lecturers, to make learning more productive.

6. Efficiently combining online learning and offline self-learning. In the offline self-learning process, students are expected to read the coursespecific literature and submit short papers based on their reading of essential materials before class. The faculty should provide feedback on student assignments and learn about students' cognitive learning levels. In the online teaching phase, the faculty should use the student discussion section to exchange their understanding based on their reading. Thus, students will not learn ambiguous, fragmented, and superficial knowledge. Instead, deep learning will be experienced during the discussion. Students in this research complained that not enough lectures and lecturers had given them too many assignments until they felt overloaded. This should be communicated as to why assignments are part of learning. However, lecturers should give feedback on the work of students, so that they know the progress of their learning.

Bao (2020) also stressed the need to provide psychological support to the university community. In this research, students viewed remote learning in both a positive and bad light. In their diaries, they wrote about confusion, depression, a devastating feeling, and some negative emotions about being isolated and learning remotely. These feelings have to be addressed. The university should provide psychological support to help students and staff manage their emotions. Their anxieties need to be relieved in a variety of ways to ensure that they can engage in online learning actively.

\section{Conclusion}

This study concluded that students experienced an ERL that utilized blended strategies of e-learning, m-learning, and conventional learning techniques. Their response to the process was paradoxical as they had both positive and negative experiences. Lecturers used significantly limited media and methods to implement learning. Moving instruction online could make teaching and learning accessible anywhere, at any time, but the speed at which this transition to online instruction is expected to happen is unparalleled. After experiencing ERL for almost a semester, and while currently waiting for government policies on how to learn next semester, it is an excellent time to learn from multiple viewpoints, including students, about their experience. Some of the feedback from this research are: preparing teachers and students for emergency learning, training lecturers on using blended resources, designing learning curricula that can be converted into online learning, developing student-independent learning skills, and providing access to a wide variety of digital reading materials. This study's findings cannot be generalized because they were based on a relatively small number of university students from one department at one university. However, 
we assume that this work presents students' views and experiences on ERL in several universities in Indonesia and probably in other countries, particularly in developing countries. More research involving more students from various universities should be initiated as a follow-up. It would also be useful to gain insights from lecturers and students at different levels of education and discuss the viewpoints of parents and other education stakeholders.

Funding: This research received no external funding.

Conflicts of Interest: The authors declare no conflict of interest in the design of the study; in the collection, analysis, or interpretation of data; in the writing of the manuscript, or in the decision to publish the results.

\section{References}

Abidin, Z. (2020). Belajar Matematika di Era Covid-19 [Studying Mathematics in the COVID19 era]. OSF Preprints. Retrieved from https://osf.io/nrbu7/

Aji, W., Dewi, F., Kristen, U., \& Wacana, S. (2020). Dampak Covid-19 Terhadap Implementasi Pembelajaran Daring Di Sekolah Dasar [COVID-19 impact on the implementation of online learning in primary schools]. Edukatif: Jurnal Ilmu Pendidikan, 2(1), 55-61. https://doi.org/https://doi.org/10.31004/edukatif.v2i1.89

Anhusadar, L. O. (2020). Persepsi Mahasiswa PIAUD terhadap Kuliah Online di Masa Pandemi [Perception of students majoring in Early Childhood Islamic Education towards online Lectures in the COVID-19 pandemic period]. KINDERGARTEN: Journal of Islamic Early Childhood Education, 3(1), 44-58.

Arbnor, I., \& Bjerke, B. (2011). Methodology for Creating Business Knowledge. In Methodology for Creating Business Knowledge. https://doi.org/10.4135/9780857024473

Bao, W. (2020). COVID -19 and online teaching in higher education: A case study of Peking University. Human Behavior and Emerging Technologies, 2(2), 113-115. https:// doi.org/10.1002/hbe2.191

Cambridge Dictionary. (2020). Paradoxical.

Casmir, F. L. (1983). Phenomenology and hermeneutics: Evolving approaches to the study of intercultural and international communication. International Journal of Intercultural Relations, 7(3), 309-324. https://doi.org/10.1016/01471767(83)90035-4

Cauchemez, S., Ferguson, N. M., Wachtel, C., Tegnell, A., Saour, G., Duncan, B., \& Nicoll, A. (2009). Closure of schools during an influenza pandemic. The Lancet Infectious Diseases, 9(8), 473-481. https://doi.org/10.1016/S1473-3099(09)70176-8

Cauchemez, S., Valleron, A.-J., Boëlle, P.-Y., Flahault, A., \& Ferguson, N. M. (2008). Estimating the impact of school closure on influenza transmission from Sentinel data. Nature, 452(7188), 750-754. https:// doi.org/10.1038/nature06732

Collins Dictionary. (2020). Paradoxical.

Concannon, F., Flynn, A., \& Campbell, M. (2005). What campus-based students think about the quality and benefits of e-learning. British Journal of Educational Technology, 36(3), 501-512. https:// doi.org/10.1111/j.1467-8535.2005.00482.x

Crescente, M. L., \& Lee, D. (2011). Critical issues of m-learning: design models, adoption processes, and future trends. Journal of the Chinese Institute of Industrial Engineers, 28(2), 111-123. https:// doi.org/10.1080/10170669.2010.548856 
Earn, D. J. D. (2012). Effects of School Closure on Incidence of Pandemic Influenza in Alberta, Canada. Annals of Internal Medicine, 156(3), 173. https://doi.org/10.7326/0003-4819-156-3-201202070-00005

Farrel, M. (2006). Learning differently: e-learning in nurse education. Nursing Management, 13(6), 14-17. https://doi.org/10.7748/nm.13.6.14.s12

Felter, C. (2020). What Is the World Doing to Create a COVID-19 Vaccine? Retrieved from https://www.cfr.org/backgrounder/what-world-doing-create-covid-19vaccine

Firman, F., \& Rahayu, S. (2020). Online learning in the middle of the COVID-19 pandemic (Pembelajaran Online di Tengah Pandemi Covid-19). Indonesian Journal of Educational Science (IJES), 2(2), 81-89. https://doi.org/10.31605/ijes.v2i2.659

Garrison, D. R., \& Kanuka, H. (2004). Blended learning: Uncovering its transformative potential in higher education. The Internet and Higher Education, 7(2), 95-105. https://doi.org/10.1016/j.iheduc.2004.02.001

Glass, R. J., Glass, L. M., Beyeler, W. E., \& Min, H. J. (2006). Targeted social distancing design for pandemic influenza. Emerging Infectious Diseases, 12(11), 1671-1681. https://doi.org/10.3201/eid1211.060255

Task Force for the Acceleration of COVID-19. (2020). Infografis COVID-19 (12 Juni 2020). Retrieved from https://covid19.go.id/p/berita/infografis-covid-19-12-juni2020

Gunawan, Suranti, N. M. Y., \& Fathoroni. (2020). Variations of models and learning platforms for prospective teachers during the COVID-19 pandemic period. Indonesian Journal of Teacher Education, 1(2), 61-70.

Hidayatullah, S., Khouroh, U., Windhyastiti, I., Patalo, R. G., \& Waris, A. (2020). Implementasi Model Kesuksesan Sistem Informasi DeLone And McLean Terhadap Sistem Pembelajaran Berbasis Aplikasi Zoom Di Saat Pandemi Covid19 [Implementation of the performance model of DeLone and McLean Knowledge Systems For Zoom application-based learning systems during the COVID-19 pandemic]. Jurnal Teknologi Dan Manajemen Informatika, 6(1). https://doi.org/10.26905/jtmi.v6i1.4165

Hodges, C., Moore, S., Lockee, B., Trust, T., \& Bond, A. (2020). The Difference Between Emergency Remote Teaching and Online Learning. Educause Review.

Institute of Medicine. (2006). Modeling Community Containment for Pandemic Influenza. National Academies Press. https://doi.org/10.17226/11800

Jackson, C., Vynnycky, E., \& Mangtani, P. (2016). The Relationship Between School Holidays and Transmission of Influenza in England and Wales. American Journal of Epidemiology, 184(9), 644-651. https:// doi.org/10.1093/aje/kww083

Juliani, A. J. (2020). THIS IS NOT ONLINE OR DISTANCE LEARNING. Retrieved from http:/ / ajjuliani.com/this-is-not-online-or-distance-learning/

Khan, F. A. (2001). Problem-based Learning Variant: Transition Phase for a Large Institution. National Library of Medicine, J. Pak Med Assoc, 51(8), 271-274. Retrieved from https:// pubmed.ncbi.nlm.nih.gov/11715887/

Khasanah, D. R. A. U., Pramudibyanto, H., \& Widuroyekti, B. (2020). Pendidikan Dalam Masa Pandemi Covid-19 [Education during the COVID-19 pandemic]. Jurnal Sinestesia, 10(1), 41-48.

Kirkwood, A. (2009). E-learning: you don't always get what you hope for. Technology, Pedagogy and Education, 18(2), 107-121. https:// doi.org/10.1080/14759390902992576

Kumparan. (2020). Anies Tutup Sekolah di DKI Jakarta Selama 2 Minggu untuk Cegah Corona [Anies closes school in DKI Jakarta for 2 weeks to prevent Corona]. Retrieved from 
https:// kumparan.com/kumparannews/anies-tutup-sekolah-di-dki-jakartaselama-2-minggu-untuk-cegah-corona-1t1V7X57VID

Lee, B. Y., Brown, S. T., Cooley, P., Potter, M. A., Wheaton, W. D., Voorhees, R. E., Stebbins, S., Grefenstette, J. J., Zimmer, S. M., Zimmerman, R. K., Assi, T.-M., Bailey, R. R., Wagener, D. K., \& Burke, D. S. (2010). Simulating School Closure Strategies to Mitigate an Influenza Epidemic. Journal of Public Health Management and Practice, 16(3), 252-261. https://doi.org/10.1097/PHH.0b013e3181ce594e

Lee, T. H. (2020). Innovations in Care Creating the New Normal: The Clinician Response to Covid-19. NEJM Catalyst, 19-21. https://doi.org/10.1056/CAT.20.0076

MacDermott, A. F. N. (2002). Living with angina pectoris - A phenomenological study. European Journal of Cardiovascular Nursing. https://doi.org/10.1016/S14745151(02)00047-6

Manfuso, L. G. (2020). From Emergency Remote Teaching to Rigorous Online Learning. Ed Tech. Retrieved from https://edtechmagazine.com/higher/article/2020/05/emergency-remoteteaching-rigorous-online-learning-perfcon

McCarthy, M. (2020, June). Dr. Anthony Fauci: COVID-19 Will End and We Will Get Control Over It. Healthline. Retrieved from https://www.healthline.com/healthnews/dr-anthony-fauci-this-will-end-and-we-will-get-control-over-it\#6

McPhee, S., \& Pickren, G. (2017). Blended learning with international students: a multiliteracies approach. Journal of Geography in Higher Education, 41(3), 418-433. https:// doi.org/10.1080/03098265.2017.1331208

Mehdipour, Y., \& Zerehkafi, H. (2013). Mobile Learning for Education: Benefits and Challenges. International Journal of Computational Engineering Research, 03(06), 93101.

Meiza, A., Hanifah, F. S., \& Natanel, Y. (2020). Analisis Regresi Ordinal untuk melihat Pengaruh Media Pembelajaran Daring terhadap Antusiasme Mahasiswa Era Pandemi Covid [Ordinal Regression analysis to see the effect of online learning media on students' enthusiasm in the COVID pandemic era]. Retrieved from http://sinta.ristekbrin.go.id/covid/penelitian/detail/361

Merleau-Ponty, M., \& Landes, D. A. (2013). Phenomenology of perception. In Phenomenology of Perception. https://doi.org/10.4324/9780203720714

Miles, M. B., Huberman, M. a, \& Saldana, J. (2014). Drawing and Verying Conclusions. Qualitative Data Analysis: A Methods Sourcebook.

Milman, N. B. (2020). Pandemic pedagogy. Phi Delta Kappan.

Ministry of Communication and Information Technology Republic of Indonesia. (2020). Penggunaan Internet di Indonesia. Ministry of Communication and Information Technology Republic of Indonesia. https://aptika.kominfo.go.id/2019/08/penggunaan-internet-di-indonesia/

Ministry of Education and Culture. (2019). The 2019/2020 Early Childhood Education Statis. Retrieved from https://doi.org/10.1017/CBO9781107415324.004

Ministry of Education and Culture. (2020a). 2019/2020 Junior High School Statistic.

Ministry of Education and Culture. (2020b). 2019/2020 Primary Education Statistics. Retrieved from http://statistik.data.kemdikbud.go.id/index.php/page/sd

Ministry of Education and Culture. (2020c). 2019/2020 Senior High School Statistic.

Ministry of Education and Culture. (2020d). 2019/2020 Vocational School Statistic.

Moscona, A. (2005). Oseltamivir Resistance - Disabling Our Influenza Defenses. New England Journal of Medicine, 353(25), 2633-2636. https://doi.org/10.1056/NEJMp058291 
National Agency for Disaster Management. (2020). Infeksi COVID-19 Telah Menyebar di 34 Provinsi di Indonesia, Total Positif Jadi 3.512 Kasus [COVID-19 infections have spread in 34 provinces in Indonesia, a total of positive to 3,512 cases]. Retrieved from https://bnpb.go.id/berita/infeksi-covid19-telah-menyebar-di-34provinsi-di-indonesia-total-positif-jadi-3-512-kasus

Patton, M. Q. (1999). Enhancing the quality and credibility of qualitative analysis. Health Services Research.

Ramdhan, D., Nasihudin, Rohaniawati, D., \& Pratiwi, I. M. (2020). TIPOLOGI BELAJAR MAHASISWA PADA PEMBELAJARAN DARING [Students' learning typology in online learning]. Digilib UIN Sunan Gunung Djati. Retrieved from http:/ / digilib.uinsgd.ac.id/30594/1/Artikel KTI dadan f ramdhan dkk .pdf

Reynolds, K. A. (2020). Coronavirus: Fauci says vaccine possible by end of 2020. Medical Economics. https://www.medicaleconomics.com/news/coronavirus-faucisays-vaccine-possible-end-2020

Sadeghi, R., Sadaghat, M. M., \& Ahmadi, F. S. (2014). Comparison of the Effect of Lecture and Blended Teaching Methods on Students' Learning and Satisfaction. J. Adv Med Ed Prof, 2(4), 146-150.

Sadique, M. Z., Adams, E. J., \& Edmunds, W. J. (2008). Estimating the costs of school closure for mitigating an influenza pandemic. BMC Public Health, 8(1), 135. https:// doi.org/10.1186/1471-2458-8-135

Saldana, J. (2009). An Introduction to Codes and Coding. The Coding Manual for Qualitative Researchers. https://doi.org/10.1519/JSC.0b013e3181ddfd0a

Saldaña, J. (2016). The Coding Manual for Qualitative Researchers (No. 14). Sage.

Salloum, S. A., Qasim M. A. A., Al-Emran, M., Abdel M. A., \& Shaalan, K. (2019). Exploring Students' Acceptance of E-Learning Through the Development of a Comprehensive Technology Acceptance Model. IEEE Access, 7, 128445-128462. https:// doi.org/10.1109/ACCESS.2019.2939467

Stephenson, J. E., Brown, C., \& Griffin, D. K. (2008). Electronic delivery of lectures in the university environment: An empirical comparison of three delivery styles. $\begin{array}{llll}\text { Computers } & E & \text { Education, 640-651. }\end{array}$ https:// doi.org/10.1016/j.compedu.2006.08.007

Suhada, I., Kurniati, T., Pramadi, R. A., \& Listiawati, M. (2020). Google Pembelajaran Daring Berbasis Google Classroom Mahasiswa Pendidikan Biologi Pada Masa Wabah Covid-19 [Classroom-online learning of Biology education students during the COVID-19 outbreak]. $\quad$ Retrieved from http:/ / sinta.ristekbrin.go.id/covid/penelitian/detail/363

Thiele, J. E. (2003). Learning Patterns of Online Students. Journal of Nursing Education, $42(8), 364-366$.

UNESCO. (2020). COVID-19 Impact on Education. Retrieved from https://en.unesco.org/covid19

Windhiyana, E. (2020). DAMPAK COVID-19 TERHADAP KEGIATAN PEMBELAJARAN ONLINE DI PERGURUAN TINGGI KRISTEN DI INDONESIA [The impact of COVID-19 online learning activities in a Christian university in Indonesia]. Perspektif Ilmu Pendidikan, 34(1), 1-8. https://doi.org/10.21009/PIP.341.1

World Health Organization. (2020a). Coronavirus disease 2019 (COVID-19) Situation Report - 42. World Health Organization. Retrieved from https://www.who.int/docs/default-source/coronaviruse/situationreports/20200302-sitrep-42-covid-19.pdf?sfvrsn=224c1add_2

World Health Organization. (2020b). Draft landscape of COVID-19 candidate vaccines 15 May 2020. World Health Organisation. Retrieved from 
https://www.who.int/who-documents-detail/draft-landscape-of-covid-19candidate-vaccines

World Health Organization. (2020c). World Health Organization COVID-19 Dashboard. Retrieved from https://covid19.who.int

$\mathrm{Wu}, \mathrm{Z}$. (2020). How a top Chinese university is responding to coronavirus. World Economic Forum.

\section{Appendix 1. Students' Diary}

Write every day about your daily learning routine. Illustrate and describe your experiences in 300-500 words a day. If you like, you can add a picture.

\begin{tabular}{|l|l|}
\hline Name: & Learning Activities \\
\hline Day/Date & \\
\hline Monday/4 May 2020 & \\
\hline Tuesday/5 May 2020 & \\
\hline Wednesday/6 May 2020 & \\
\hline Thursday/7 May 2020 & \\
\hline Friday/8 May 2020 & \\
\hline Saturday/9 May 2020 & \\
\hline Sunday/10 May 2020 & \\
\hline Monday/11 May 2020 & \\
\hline Tuesday/12 May 2020 & \\
\hline Wednesday/13 May 2020 & \\
\hline Thursday/14 May 2020 & \\
\hline Friday/15 May 2020 & \\
\hline Saturday/16 May 2020 & \\
\hline Sunday/17 May 2020 & \\
\hline Monday/18 May 2020 & \\
\hline
\end{tabular}

\section{Appendix 2. Reflective Essay}

Write your thoughts on the implementation of emergency remote learning that has been going on for more than 2 months in 500-1000 words. Write down what you like and do not like about ERL. 